\title{
CAN ACCOUNTING INFORMATION ACT AS A PROXY FOR EX ANTE UNCERTAINTY IN INITIAL PUBLIC OFFERINGS?*
}

\section{Tatang Ary Gumanti}

This paper revien's and summarizes previons works and the rationale for the proposition that accounting information is in fact value relevant in the determination of an initial pablic offering (IPO). Theoretical and empirical evidence has indicated that certain accounting measures can be used as proxies for total firm risk, that is, they could determine the riskiness of a corporation. The literature also advocates that accounting information is relevant in determining the value and thus the riskiness of a corporation through the use of accounting analysis. Since most of the information available in the prospectus is accounting information, it is arguable that this information represents a potential source for assessing the issuing firm. Some scholars have also advocated the possibility of using accomming information in assessing the value of firm making an IPO.

Numerous papers have provided analytical and empirical evidence of the association between accomting mumbers and the value of IPOs. The conclusion generally comes to show that information in the prospectus is value relevant concerning the IPO. The paper show's that it is indeed an arguable to use accounting information in the valuation of an IPO. Accordingly, it is an empirical issue whether accounting information has the property in explaining the ex ante uncertainty of an IPO.

Keywords: accounting information: ex ante uncertainty: initial public offering (IP()): underpricing

'Acknowledgement:

I am indebled to Asley Brown for comments on the early draft of the paper and the grammatical correction and an anonymous reviewer for comments. 


\section{Introduction}

This paper provides a summary of previous works and the rationale for the proposition that accounting information is in fact valuc relevant in the value determination of an initial public offering (IPO) and thus the prediction of IPO ex ante uncertainty. Analytical and empirical evidence of the association between accounting numbers and the value of IPOs are provided in numerous papers, for example, Downes and Heinkel (1982), Titman and Trueman (1986), Krinsky and Rotenberg (1989a; 1989b), Kim et al. (1994; 1995a; 1995b), and Klein (1996). Kim et al. (1995b) and Klein (1996), in particular, show that accounting information in the prospectus is value relevant conccrning the IPO.

Theoretical and empirical evidence has indicated that certain accounting measures can be used as proxies for total firm lisk, that is, they could determine the riskiness of a corporation (Lev 1974; Bowman 1979; DeAngelo 1990). The literature also suggests that accounting information is relevant in determining the value a corporation through the use of accounting analysis (White et al. 1998). Since most of the information available in the prospectus is accounting information, it is arguable that this information represents a potential source for assessing the issuing firm. Advocales on the possibility of the use of accounting information in assessing the valuc of firm making an IPO are provided in Beaver et al. (1970), Foster (1986), Lev (1989), Ryan (1997), and Noland and Pavlik (1998). The possibility of incorporating accounting information for measuring the risk of a firm making an IPO in the absence of ex post risk measures prior to the offering is thus an empirical issue.
There is a considerable and growing body of empirical evidence suggesting that the IPOs of common stocks arc. on average, underpriced. This underpricing is a widespread phenomenon and is evidenced across many capital markets (Loughran et al. 1994). A number of theoretical models have been proposed to explain the phenomenon. For example, Baron (1982) develops an underpricing model based on information asymmetry between the issuing firm and underwriters, while Rock (1986) models underpricing as a result of information asymmetry between investors. Others develop underpricing theories based on signaling hypothesis arguing that the underpricing is a means of conveying a good quality IPO (Grinblatt and Hwang 1989; Welch 1989).'

The IPO underpricing theories assert that the pre-trading or ex ante uncertainty about the aftermarket price is the driving factor for the extent of underpricing. Generally, the theories come to a similar implication that underpricing is positively related to the ex ante uncertainty about the aftermarket price of the issue. In other words, the expected amount of underpricing increases as the uncertainty about the aftermarket of the issue increases. Empirical support for this positive association has been shown in many research papers. This paper examines the association between accounting measures of total firm risk and the degree of underpricing of common stocks. Five accounting risk measures are reviewed, namely financial lcverage, operating leverage, size, growth, and profitability. The paper is able to draw conclusion that the accounting information risk measures are value relcvant for determining the IPO of common stocks.

' Ibbotson et al. (1988: 1994) provide the summary of theories explaining why IPOs on average are underpriced 
Tatang Ary Gurnanti - Can Accounting Information Act as a Proxy for Ex Ante...?

This paper proceeds as follows. Section two provides the importance of accounting numbers in an asset or company valuation and IPO. Section three is concerned with the theoretical analysis that supports the view that accounting numbers are value relevant. Section four provides a summary of the empirical evidence. Section five elaborates accounting variables perceived to be related to IPO ex ante uncertainty. The final section concludes the paper followed by some important recommendations.

\section{Accounting Information and IPO's Value Determination}

There have been a number of empirical studies suggesting the consistent and significant role of accounting numbers as a determinant of stock returns (see for example. Bernard 1995; Abarbanell and Bushee 1998). Also, recent theoretical explanation has shown that accounting numbers indeed have value properties in explaining the value of companies. i.e., their stocks (Ohlson 1995; Feltham and Ohlson 1995). Morcover, an investor could earn abnormal returns by performing fundamental analysis (Sce for example, Chan et al. 1991; Chung and Kim 1994; Ballester and Livnat 1997; Setiono and Strong 1998).

The literature suggests that accounting numbers are potentially useful in the process of price detcrmination of IPOs. Beaver et al. (1970) argue that accounting data offer superior forecasts of the market determined risk measures and conclude “... accounting risk mcasures can be applicd to decision-settings where market determined risk measures are not available. Two such situations immediately come to mind: privately' held firms 'going public' for the first time..." (p. 680. emphasize added). Foster (1986) describes "there are many contexts in which estimates need to be placed on the value of companies that are not traded on organized markets, for example ... (b) when determining the price at which a company. could go public..." (p. 422, emphasize added). Lev (1989) challenges researchers by asking "What is the role of financial variables in unusual circumstances when market variables are nonexistent or are of limited usefulness. These include the role of financial variables in the valuation of new' public firms (initial public offerings) ..." (p. 179, cmphasize added). Berstein and Wild (1998) also suggest the use of financial fundamental ratios in estimating equity values of companies whose stocks are not traded in active markets. Finally. Noland and Pavlik (1998) also call for accounting researchers to examine the value relevance of accounting numbers as the detcrminants of IPO offer price, as they question "How are market prices determined for private stock, and, in particular, what is the role of accounting number:s in the valuation estimate?" (p. 94, emphasize added).

Thus, there have been numerous suggestions about the potential use of accounting information in the price determination of IPO of common stocks. Kim ct al. (1995b) and Klcin (1996) provide evidence on the importance of accounting variables contained in the issue prospectus in the pricing of Korean and US IPOs, respectively. Many studies appear not to specifically examine the association between accounting information and the degree of underpricing, although most of them have included accounting numbers in their models. 


\section{Can Accounting Information Act as a Proxy for IPO Ex Ante Uncertainty}

There secms to be an ongoing contention whether accounting information is value relevant in the determination of an IPO. Empirical evidence provided in various papers (Sec Table I) seems to support, implicilly and partially, that this assertion is supported. Anderson et al. (1995) assert that the success in testing ex ante uncertainty of an IPO depends heavily on the success in selecting the variables. Thus, it seems that whether accounting risk measures can be used in pricing an IPO is still an empirical question. However, the following advocales suggested by numerous scholars seem to support that accounting risk measures are indeed the potential sources in valuing an IPO.

According to the Statement of Financial Accounting Concept (SFAC) No. 1 of the Financial Accounting Standards Board (1978: p. 5), the primary objective of accounting is to provide information useful lor investment decision-making, i.c., the picture of a company, which later can be used to make rational judgments. SFAC No. 1 (p. 5-8) also postulates that accounting information can be useful in changing or refining the beliefs and expectations of investors or interested parties since accounting data measures the economic lundamentals of a company (See also Beaver 1986).

The accounting literature suggests that one of the major roles of accounting is 10 provide information on the structure and functional behaviour in performance evaluation of a business corporation that is useful for all types of users. For example, cmpirical studies have shown that account- ing information is used to predict bankruptcy, determine bond rating, evaluate equity risk. and to evaluate the performance of corporate contracts (Watts and Zimmerman 1986; DeAngelo 1990; White et al. 1998). This suggests that accounting information has been widely used in corporate valuation.

Furthermorc, Kaplan (1978) and Watts and Zimmerman (1986) conclude that accounting numbers do have information content and are useful in cletermining stock returns. Kaplan asserts that there arc two important roles of accounting dalta: they affect the unexpected security returns and they affect the riskiness of a security. Brennan (1995) also suggests that accounting information is considered as value relevant for determining stock prices. Thus, at this stage, it appears that the uselulness of accounting information in detcrmining the riskiness of a security has been widely acknowledged.

Following Ball and Brown's (1968) seminal paper that linds a significant association between carnings and returns, there has been a long debate concerning the role of accounting variables for stock price valuation. Lev (1989) argues that, allhough there is a statistically significant relationship between earnings and returns. the explanatory power are still low, indicating a lack of economic significance. Equipped with refined rescarch designs, accounting researchers have further provided evidence that some accounting variables, taken from the firm's financial statements, are value relevant and could be used to predict stock prices (See for example, Ou and Penınann 1989; Holthausen and Larker 1992; Chung and Kim 1994; Ballester and Livnat 1997; Scliono and Strong 1998). Black et al. (1997) find strong evidence of the useful- 
ness of financial statement information in explaining futurc profitability for emerging-growth firms. ${ }^{2}$

Altempts $(0)$ further refine the possible relation between accounting numbers and the value of a firm are proposed by Ohlson (1995) and Feltham and Ohlson (1995), and empirically tested by Bernard (1995). They argue, theoretically, that basic accounting variables, such as earnings, return on equity, and book values could be used to express firm value and thus are relevant for stock price valuation. This theoretical analysis appears to underpin the notion that some accounting variables are valuc relevant and accordingly are regarded as important factors for determining the true value of a firm and, thus, the riskiness of the firm. Bauman (1996) and Ryan (1997) conclude that financial statements contain information useful for prediction of firm value.

At this stage, it is clear that accounting information is value relevant for securities price determination. Thus, given that there is support for the usefulness of accounting information as a risk determinant in corporate valuation, it is therefore necessary to identify which accounting information is persistently related to risk.

Beaver et al. (1970) examine the relationship between accounting information and total and systematic risk. They posit that accounting information also has value relevance given that the accounting system generates information that could be considered as a measure of risk. They argue that accounting risk measures can be employed as surrogates for tolal variability of returns that reflect either the systcmatic or individual risk components. As accounting information can reflect a firm's risk, it is reasonable to use them as surrogates for fïms' systematic risk. To test their hypothesis. Beaver et al. ran regressions between markets determined systematic risk and selected accounting risk measures and found that dividend payout ratio, asset growth, financial leverage, liquidity, asset size, earnings variability. and earnings covariability are related to the market-based risk measure. Beaver et al. go on to assert that accounting information implicitly supplies assistance for risk assessment. Belkaoui (1978), Eskew (1979) and Dhingra (1982) also found that their selected accounting measures have superior ability in predicting systematic risk.

Other studies have focused on the examination of single or ccrtain accounting variables. Lev (1974) finds an association between total risk and operating leverage. Ben-Zion and Shalit (1975) also find that firm size, financial leverage, and the dividend record determine systematic equity risk. Brealy and Myers (1996) arguc that financial leverage is related 10 security returns because the introduction of new debt may cause investors to believe that the firm is more risky leading them to ask for higher returns. Further. Christie (1982) posits that the variance of equity returns is a function of financial leverage.

Myers (1977) identifies four accounting measures, namely the covariance of earnings, earnings variability, financial leverage, and growth that are related to the measures of market systematic risk (bela) (p. 60-64). Myers asserts that size is also a measure of total risk, i.c. large firms will have lower total risk. Ryan (1997) concludes that the variables that consistently relate to systematic equity risk are carn-

\footnotetext{
2 Note that as one of the basic characteristics of IPO firms is as growing company. Black's et al. (1997) findings could be representative and be generalized to IPO firms.
} 
ings variability, sources of operating risk, financial leverage, and operating leverage.

Given that accounting risk metsures can act as a proxy for total firm risk and given also that systematic risk and total risk are correlated, accounting risk measures that are related to systematic risk must also relate to unsystematic risk. Thus, it can be argued that accounting information, in particular accounting risk measures, are potential determinants for the riskiness of a security, and thus a company.

In addition, it appears that financial analysts in various countries regard accounting information as potentially useful in explaining the common stocks systematic risk. This evidence is found in the US (Farrelly el al. 1985), New Zcaland (Mcar and Firth 1988), Japan (Hall et al. 1994), the UK (Capstaff 1992), and Hong Kong (Selva 1995).

Studies in Indonesia also indicate that some accounting variables are significantly related to systematic risk. Tandelilin (1997a, 1997b) finds an association between long-term debt to total assets, net worth to total assets, the quick ratio, current assets to total assets, firm total assets, and net profit margin and the systematic risk of common stocks of Indonesian public firms. This empirical finding appears to confirm that accounting information is regarded as value relevant to determine the riskiness of Indonesian securities and thus corporations.

There is also a suggestion that a number of selected financial ratios based on the published financial statements of Indonesian public fïms can adequately be used to predict future earnings (Machfoedz 1994). This finding, ceteris paribus, shows that certain accounting variables are informative for investors in the Indonesian capi- tal market and are useful for the valuation of a security, suggesting that the systematic risk of Indonesian public corporations is related to financial accounting information.

In summary, it has been shown that accounting information is a potential determinant of the riskiness of a corporation. Among accounting numbers that have consistently been related to company risk are financial leverage, operating leverage, company size, earnings or profitability ratios, and growth. Recent theoretical development and empirical evidence has shown that accounting numbers are related to market measures of risk. Many studies have also provided evidence that investors could earn abnormal returns by performing fundamental analysis.

As noted earlier, the IPO literalurc has suggested that accounting numbers, such as carnings, sales, and book value are useful in the pricing and valuation of an IPO (Sutton and Benedetto 1988; Buck 1990). Ryan (1997) notes that in the absence of ex post measure of risk, such as in the case of IPO, the firm's risk is estimated through the use of (mostly current) accounting variables. This asserts the potential role of accounting information in the risk estimation of an IPO. In addition to this, Beaver et al. (1970), Foster (1986). Lev (1989), Berstein and Wild (1998), and Noland and Pavlik (1998) also suggest a possible use of accounting information for the valuation of privately held lirms wishing to go public.

Outside investors who do not actively engage in firm corporate governance may rely on the issuing firm' $s$ financial statements, as in its prospectus in the case of IPO, to value their claims because accounting data potentially reflects issuers' propriclary business information. However, the accuracy of accounting in- 
lormation. in particular an IPO, may be subject to the issuers' incentive to bias the numbers in their best interest. ${ }^{3}$ This problem eventually could be reduced by the existing accounting regulations that restrict the issuers' ability to distort financial clata. Auditors' verification could also increase the reliability of financial statcments (Healy and Palepu 1993; Palepu et al. 1996; White et al. 1998). Thus, it is likely that, the new issue market's investors use their judgment by utilizing information available in the issue prospectus. The absence of publicly available information about the issuing firms makes information available in the issue prospectus one potential information source for the valuation of the IPO. The available accounting information, along with the signals shown by the issuers, may serve as a key factor in determining the price and thus the value of an IPO. It also appears that certain accounting variables can be used as a proxy for total firm risk and thus can be used as a proxy for ex ante uncertainty, which accordingly are appropriate for testing the IPOs underpricing equilibrium (See Table 1).

In addition, it is widely understood that the level of accuracy and quality of accounting information has been a primary concern for investors in the IPO market. Beatty (1989) provides strong evidence that the IPO firms audited by prestigious auditors have relatively lower ex ante uncertainty (underpricing). Beatty argues that high quality auditors provide more precise audit services allowing mar-ket participants to make more precise estimates of the distribution of lirm value. Bcatty's finding is supported by Allieck-
Graves et al. (1993) and How (1996). Michaely and Shaw (1998) also find that the selection of underwriter and auditor is related to the financial performance of the IPO firms. Thus. ceteris paribus. more prestigious auditors could reduce the ex antc uncertainty. This implies that there is an inverse relationship between more precise accounting information and $\mathrm{cx}$ ante uncertainty suggesting that accounting numbers supply information about the ex ante uncertainty of an IPO.

To summarize, certain accounting numbers appear to be useful for the assessment of the riskiness of a security. Finally, hecause total risk is positively correlated to ex ante uncertainty, and given accounting risk measures are potential proxics for total firm risk, we can argue that they can be used as proxies for ex ante uncertainty.

The puzzling phenomenon of the IPO has attracted significant interest among researchers. Most of the existing rescarch on IPOs examines the cross-sectional differences of initial returns and most are designed to test the theories of underpricing. Other IPO studies include the valuation study, the short and long run performance of IPOs study, and the IPO pricing study.

Early studies on the valuation of IPOs generally depart from the signalling hypothesis proposed by Leland and Pyle (1977) and examined empirically by Downes and Heinkel (1982) and How and Low (1993). The studies have generally supported the notion that the accounting variables are partly or jointly associated with the value of IPOs (Downes and Heinkel 1982; Ritter 1984; Krinsky and Rotenberg 1989a, 1989b; Clarkson et al.

\footnotetext{
3 Accounting in formation of the US IPOs of common stocks has been subject lo earnings manipulation (Sce for example. Friedlan 1994: Magnan and Cormier 1997: Teoh el al 1998). Aharony et al., (1993). however. do not support this evidence. There is atso no evidence that issuers of Indonesian IPOs manage their accounting ciarnings in the periods prior to the offering (Gumanti 1996).
} 
1991; McGuinness 1993; Kim et al. 1994; Kim and Ritter 1999). Most of the studies find that the value of the IPOs is significantly related to the level of ownership retention, the level of debt, the quality of underwriters or investment bankers, the proposed use of the proceeds, firm size, excess returns, and accounting earnings.

Other studies focus on the examination of the pricing of IPOs (Kim et al. 1995b; Klein 1996). Kim et al. and Klein are probably the only studics that explicitly provide direct tests of the pricing of IPOs using information available in the issue prospectus, with reliance more on accounting information. These studies show that the IPO firms' financial variables significantly affect the market price of the issue. This finding supports the notion suggested in the literature that accounting information is used as an input into the pricing of an IPO.

\section{Summary of Empirical Evidence}

Recall that the underpricing theories suggest the magnitude of underpricing is positively related to the $\mathrm{cx}$ ante uncertainty surrounding the issue. Taking the raw or adjusted initial returns as the dependent variable and regressing over various proxies for ex ante uncertainty, the studies find that some proxies are consistently related to the degrec of underpricing. Table 1 provides a summary of studies relating initial IPO returns and various proxics for ex ante uncertainty. Many studies involve accounting variables in their regressions. Thesc accounting variables include the level of debt (financial leverage), prolit level or profitability, operating leverage measured as the ratio of plant assets to lotal assets, and IPO or firm size. The lindings however are mixed. The is- sue size appears to be consistently and negatively related to the degree of underpricing.

As shown in Table 1, support for the notion that certain accounting information available in the issue prospectus could explain the cross-sectional variation of the lcvel of underpricing is advanced. The evidence clearly indicates that, to a certain extent, accounting information is value relevant for the determination of the price of an IPO.

\section{Accounting Variables as Proxies for Ex Ante Uncertainty of IPO}

This section provides the theoretical explanation and empirical evidence of the relationship between some accounting variables and the ex ante uncertainty of an IPO, and thus the degrec of underpricing. These accounting variables include financial leverage, operating leverage, asset growth, firm size, and the level of profitability. Each of these is discussed in further detail below.

\section{Financial Leverage}

The finance literalure suggests that the variability of firm value is affected by the introduction of debt into its capital structure. When debt is introduced into a firm's capital structure, a more volatile earnings stream results. This will increase the risk of common stocks, which leads the shareholders to demand a higher return (Brealy and Myers 1996). Early studies by Hamada (1969) and Rubenstein (1973) show that firm risk is a function of financial leverage. Ben-Zion and Shalit (1975) and Christie (1982) also confirm that such a relationship does exist. Dhingra (1982) acknowledges that financial leverage is regarded as one of the predictors of firm 
Table 1. Summary of Studies Relating IPO Initial Returns to Various Proxies for Ex Ante Uncertainty

\begin{tabular}{|c|c|c|c|c|c|c|c|c|c|c|c|c|c|}
\hline Stady & $\begin{array}{l}\text { Offer } \\
\text { Size }\end{array}$ & $\begin{array}{l}\text { Firm } \\
\text { Size }\end{array}$ & $\begin{array}{l}\text { Owner- } \\
\text { ship } \\
\text { Level }\end{array}$ & $\begin{array}{l}\text { Firm } \\
\text { Age }\end{array}$ & $\begin{array}{c}\sigma \\
\text { of } \\
\text { Returm }\end{array}$ & $\begin{array}{c}\text { U W } \\
\text { Quality }\end{array}$ & $\begin{array}{l}\text { Auditor } \\
\text { Quality }\end{array}$ & $\begin{array}{c}\text { Bank or } \\
\text { Deht } \\
\text { Dummy }\end{array}$ & $\begin{array}{l}\text { Debt } \\
\text { Equity } \\
\text { Ratio }{ }^{2}\end{array}$ & Profit $^{(2)}$ & PATA ${ }^{\text {(4) }}$ & Country & $\begin{array}{l}\text { Sample } \\
\text { Size } \\
\text { (Years) }\end{array}$ \\
\hline Buckland and Davies (1990) & $(+)$ & & & & & & & & & $(-)^{*}$ & & UK & $331(80-85)$ \\
\hline Wethyavivom and Koo-Smith (1990) & $(-)^{n}$ & $(-)$ & & & & & & & $(+)$ & & & Thailand & $32(88-89)$ \\
\hline James and Wier (1990) & $(\cdot)$ & & $(-)$ & $(-)^{4}$ & & $(-)$ & & $(-)^{\mu}$ & & & & US & $549(80-83)$ \\
\hline Keasy and Short (1990) & $(t+4$ & $(-)^{\mu}$ & $(t)$ & $(+)$ & & & & & & $(-\mu$ & & UK & $222(84-88)$ \\
\hline Garfinkel (1990) & $(-)$ & & & $(-)^{2}$ & & $(-)$ & & $(-\mu$ & & & $(-)$ & t'S & $549(80-83)$ \\
\hline Afleck-Graves et al. (1993) & $(-)^{2}$ & $(+)^{3}$ & $(-)$ & $(-)^{4}$ & $(+)^{2}$ & $(-)^{n}$ & $(-)^{\mu}$ & & & & & US & $1.078(83-87)$ \\
\hline Kim et al. (1994) & $(-)^{n}$ & & Mixed & & & Mixed & & & Mixed & $(+)^{n}$ & & Korea & $177(88-90)$ \\
\hline Clarkson (1994) & $(-)$ & $(-)$ & & $(-)^{n}$ & & $(+)$ & $(+)$ & & & & & US & $420(76-85)$ \\
\hline How (1996) & $(-)^{2}$ & & & $(-)^{2}$ & $(t)^{2}$ & $(-)$ & Mixed & & $(+)^{*}$ & $(-1)$ & & Australia & $200(79.90)$ \\
\hline Hedge and Miller (1996) & $(t)^{n}$ & & $(\cdot)^{2}$ & $(-)$ & $(+)^{2}$ & $(-)^{n}$ & $(-)^{\mu}$ & & $(*)^{n}$ & & & is & $890(81-85)$ \\
\hline Michaely and Shaw (1998) & & $(-)$ & & & & $(-)^{4}$ & & & $(-)$ & $(-)$ & & US & $809(84.88)$ \\
\hline Gumanti $(2000)$ & $(-)$ & $(-)^{4}$ & $(+)$ & $(-)$ & $(t)$ & $(\cdot)$ & & & $1+t^{2}$ & $(+)$ & $(-)^{n}$ & Indonesia & $149(89.97)$ \\
\hline
\end{tabular}

$\therefore$, and " denote coefficients being significantly different from zero at the one, five, and ten percent levels, respectively.

"The measure of firm size usually takes two forms: total assets or sales.

(2) There are various measures for debt to equity ratio.

(3) Profit is measured either as the level of profits or profitability ratios.

(t) PA/TA is the ratio of plant assets to total assets. 
risk. Gahlon (1981), Gahlon and Gentry (1982), and Mandelker and Rhee (1984) provide theoretical models, and empirical evidence that financial leverage is a potential determinant of tirm risk.

Empirical evidence in an IPO selting, however, provides mixed results. Kim el al. (1994) lind a signilicant positive relationship between financial leverage and initial excess returns in a study of Korean IPOs. How et al. (1995) find no significant rclationship between financial leverage and the degrec of underpricing in their study of Australian IPOs, but using a reduced sample they find a significant positive relationship. In contrast, James and Wier (1990) find that IPOs with a history of a borrowing relationship experience lower underpricing than those without a borrowing relationship. Further, James and Wier posit that $\mathrm{ex}$ ante uncertainty is decreasing in a firm's pre-IPO capital structure upon the existence of debt. Slovin and Young (1990) also find that the presence of bank debt and/or lines of credit in the capital structure of a firm prior to IPO is negatively related to IPO initial returns. Garfinkel (1993) also documents that the existence of debt in a lirm's pre-IPO capital structure reduces the level of underpricing. In addition to this. Anderson et al. (1995), in a review of the IPO literalure, conclude that the degrec of underpricing increases with the level of debt.

Hedge and Miller (1996) argue that the existence of debt prior to the offering ol an IPO can be used as a signal about the quality of the issuc. Their hypothesis is developed on the basis of the financial signaling literature that suggests that one of the primary means used by a high quality firm is debt financing (Leland and Pyle 1977; Myers and Majlul 1984). Hedge and
Miller argue that issuers of a high quality firm use larger amounts of debt prior to the offering to signal that the firm has high quality prospects. A high quality firm uses debt either to mitigate inefliciencies in its investment decisions or to signal its private information to the market. Hedge and Miller point out that there is a greater probability that outsiders will have the opportunity to detect the firm's ability to service its debt obligations the larger the firm's debt. In other words, pre-IPO debi serves as a proxy for a firm's future prospects. Their finding supports their proposition of a negative and signilicant association between the level of IPO lirms" debt prior to the oflering and the degree of underpricing.

\section{Operating Leverage}

There have been a number of suggestions, theoretically and empirically, about the perceived usefulness of operating leverage as a determinant of firm risk (Lev 1974; Gahlon 1981; Gahlon and Gentry 1982; Mandelker and Rhee 1984: O'Brien and Vanderheiden 1987). The literature also advocites that operating leverage is a potential determinant of firm risk, as shown by its effect through operating risk (White cl al. 1998).

Lev (1974) finds operating risk measured as the ratio of fixed operating costs to variable operating costs is positively associated with total firm risk. Such an association occurs because the increase in the proportion of lixed costs is followed by an increase in volatility of returns. Since information about an IPO, as disclosed in the prospectus, is limited to a maximum of three years of financial statements. Lev's approach is not applicable in an IPO setting. Accordingly, given this 
data limitation a proxy for operating leverage is required. ${ }^{4}$

One potential candidate for the proxy for operating leverage is capital intensity: "a measure of the amount of assets required per dollar sales" (Brigham and Gapenski 1991, p. 933). They point out that capital intensity is one of the greatest inlluences on a firm's external funding requirements." Capital intensity can be expressed as the ratio of sales to total assets, that is a reciprocal of total assets turnover (Brigham and Gapenski 1991). This ratio suggests the amount of assets required to generate sales. A higher ratio means that more assets are required to obtain sales, which could be perceived as the firm having a lower utilization of its assets. O'Brien and Vanderheiden (1987) reason this ratio may serve better than the other operating leverage proxies (such as fixed to total assets ratio) because it provides a morc reasonable gauge of the intensiveness of physical capital relative to labor and raw material (see Rosenberg and McKibben 1973). A higher ratio means that the firm is engaging in low asset intensiveness. Accordingly, a firm with a higher assets to sales ratio is said to be less attractive and thus more risky. Empirical studies have paid little, if any, attention to the potential influence of operating leverage as a determinant of IPO initial return. Garlinkel (1993), who uses the ratio of plant assets to total assets, finds a negative. but insignilicant, relationship.

To summarize, a large number of empirical studies have found an inverse and significant relationship between IPO size and the degree of initial excess returns. However, as firms are likely (o) reduce the capital intensity ratio to obtain external financing, it is expected that a higher capital intensity ratio (i.e., operating leverage) is associated with higher initial returns.

\section{Firm Size}

Beaver et al. (1970) point out that firm size can be used as a proxy for the total risk of a firm. Ritter (1984) proposes an argument that more established firms (usually larger firms) are less risky than less established ones, because more is known about them and they are easier in value. Using size as a proxy for ex ante uncertainty, Ritter provides support for his argument. Barry and Brown (1984) also suggest that there is a positive relationship between firm size and firm specific information. That is, larger IPOs arc more likely to be related to lower risk and thus lower ex ante uncertainty.

Assuming that large firms have a more diversified asset base, if the value of the assets of the firm is less than perfectly correlated we may expect that larger firms have a lower variance of rate of retuin than smaller ones. Whittington (1980) suggests that larger firms tend to have at wider spectrum of activities, suggesting that their share prices and returns on equity are relatively more stable. Ben-Zion and Shalit (1975) note that when size is used as a proxy for cconomies of scale, firms arc able to incur lower costs and earn ec()nomic rents. Ibbotson et al. (1988; 1994) find IPOs with lower sales prior to the

\footnotetext{
+O'Brien and Vanderheiden (1987) suggest the use of a static proxy. They examine four proxics, namely depreciation to total assets ratio, depreciation to sales ratio, total assets to sales ratio, and fixed assets to total assets. Yet. none of the variables is found to be significant.

'Brigham and Gapenski (1991) also note that projected sales growth, initial fixed asset utilization rate (excess cupacity situation), profit margin. and dividend policy are identified as other factors influencing a firm's external funding requirement.
} 
offering are more underpriced than ones with larger siles, and they suggest that sales may be used as a proxy for the level of investor's uncertainty regarding the issuing firm.

Although most of the studies find negative relationships between initial return and firm or issue size, some still document a positive and significant relationship (for example. Affleck-Graves et al. 1993). Indonesian studies also show mixed findings. For example, Sautma (1998) finds a positive coefficient for sales and a negative coefficient for issue size (gross proceeds), although neither proxy is statistically significant. A similar finding is reported in Rizka (1995).

\section{Firm Growth}

Fewings (1975) and Turnbull (1977) argue that the growth of a firm (either represented by sales or assets) may reflect a substantial element of business uncertainty. Firms with constant or stable growth are regarded as having less uncertainty and being less risky. These firms are usually those that are able to maintain their business and tend to have a longer operating history.

In contrast, firms that experience faster growth (which tend to be young firms) are subject to greater uncertainty and, therefore, are perceived to be more risky. These firms are usually those that are in the early stages of their existence, which is a common characteristic of IPO firms. and tend to experience excessive sales growth. This is in line with Hall and Renner (1988) who note that the success of an IPO usually rests on a sharp increase in sales, suggesting that, ceteris paribus, onc indication of the success of the operalions of an entity sceking capital through an IPO is an increase in sales. Given that high growth firms possesses high uncer- tainty and thus more risky, the correlation between firm growth and IPO initial return is positive.

\section{Profitability}

The level of profitability is examined because an investor's judgments about the effectiveness of business operations may be determined by past profitability. It is argued that high profitability may reduce ex ante uncertainty since highly profitable IPOs may alleviate investors' concern about the effectiveness of management. Krinsky and Rotenberg (1989a) also contend that the profitability of existing operations may provide outsiders with evidence of management effectiveness, and a high profit margin may reduce concerns over the historical level of management shirking or perquisites consumption.

Profitability has been regarded as a potential proxy for the riskiness of an IPO (Beatty and Zajac 1995). It is also not uncommon that a profitable IPO firm is more attractive than a less profitable one. An IPO firm with a negative profit is regarded as being exposed to greater risk that one with a positive profit. This suggests that an inverse relationship exists between profitability and risk in an IPO setting.

In addition, it has been widely recognized that earnings have information content, that is, accounting earnings supply information for stock price valuation. Kaplan (1978) and Watts and Zimmerman (1986), based on their review, concluded that accounting earnings, from the efficient market hypothesis point of view. rellect factors that affect stock prices. Thus, earnings or earnings levels are useful for stock price assessment. Earnings have also been used as a standard input in the valuation of IPOs (Pcrez 1984; Bloch 1986: Sutton and Benedetto 1988; Buck 199(): 
Benninga and Sarig 1997, among others). This suggests that earnings are one of the potential determinants of an IPO issue price. Aggarwal and Rivoli (1990) find that firms with low or negative income tend to exhibit higher issuance costs. These issues are more likely to be marginally undersubscribed, which will increase the risk faced by the investment banker. Thus, IPO firms having low or negative income, and thus carnings, are perceived to be more risky than those with positive income.

Sterling (1987) points out that one of the key factors to the suceess of an IPO is that the issuing firm must have a good quality of carnings. Hall and Renner ( 1988) also assert that the success of IPOs usually rests on earnings trends. Empirical evidence, however, provides mixed findings. Buckland and Davies (1989), as cited in Keascy and McGuinness (1992), and Keascy and Short (1992) find that the issuc price discount is inversely related to the IPO firm's past profits. There is another study that does not provide strong support for the view that profitability is associated with initial abnormal returns in the new issues market (Kim ct al. 1994). Kim ct al. find a negative but insignificant association between profitability and IPO initial returns in their study of Korean IPOs. In contrast to Kim el al. (1994), Pettway and Kaneko (1996) find a positive hut insignificant relationship in their study of Japanese IPOs. Michaely and Shaw (1998) also report a similar finding.

IPO firms with (greater) profitability are perceived to have been better able to manage their husiness, and thus have $c x-$ hibited lower risk, it is expected that more profitable IPOs cxperience lower initial returns. Since it can be argued that faster growing lirms are more risky, it is expected that, as growth increases. initial return should increase. Investors will demand higher abnormal returns to compensate for the risk they are bearing. Thus. it is expected that as growth increases initial return should increase.

\section{Conclusions and Recommendations}

The regulators of Indonesian IPOs appear to be concerned with level of prolitability. One of the common stock listing requirements states that firms wishing to make an IPO must have posted operating profits in the last two fiscal years of operation. Thus, profitability is considered crucial in Indonesian IPOs. However, as has been stated in the requirement, an IPO firm may not be required to have posted a prolit when it has just started the business.

Theoretical explanation and cmpirical evidence appear to suggest that accounting information is value relcvant in the detcrmination of firm value and for firms wishing to go public. As shown empirically, some accounting numbers are known of being the potential proxics for the uncertainty surrounding an IPO. This may not be surprising. since most of the information available in the prospectus is accounting information. Thus, it is arguable that this information represents a potential source for assessing the issuing firm. Five accounting variables are identified being the potential proxies for $\mathrm{cx}$ ante uncertainty in an IPO price determination. These include financial leverage, operating leverage, lirm si\%e, asset or firm growth, and profitability.

Following the conclusions and given the strong theoretical judgment that accounting information (variables) is used by various users for various proposes, i.e., contracts and monitoring. lurther study may attempt to challenge the hypothesis 
that accounting information is related to the degree of underpricing. This is likely to be inevitable considering that most information provided in the issue prospectus is dominated by accounting numbers (information) forcing investors to utilize that information in their buy or hold decision of an IPO firm.

The possibility of utilizing accounting information for measuring the risk of a lirm making an IPO in the absence of ex post risk measures prior to the offering is thus an empirical issue. Given the rcgulations surrounding the process of making an IPO in an Indonesian setting, which put reliance on the accounting numbers, study that specifically examine the relationship between accounting risk proxy and the uncertainty of an IPO, i.e., the initial return seems to be promising. However, attention must be taken into consideration regarding the relevance of selected accounting information to be the proxy of risk. As pointed by Anderson et al. (1995) that the success in testing the determinants of IPO initial return depends heavily on the success of selecting the proxy.

\section{References}

Abarbanell, J. S., and B. J. Bushee. 1998. Abnormal returns to a fundamental analysis strategy. Accounting Review 73 (1): 19-45.

Aflleck-Graves, J., S.P. Hegde, R.E. Miller, and F.K. Reilly. 1993. The effect of initial trading system on the underpricing of initial public offerings. Financial Management 22 (1): 99-108.

Aggarwal, R., and P. Rivoli. 1990. Fads in the initial public offering market'? Financial Management 19 (4): 45-57.

Aharony, J., C. J. Lin, and M. P. Locb. 1993. Initial public offerings, accounting choices, and earnings management. Contenporary Accounting Research 10 (1): 61-81.

Anderson, S. C., T. R. Beard, and J. A. Born. 1995. Initial Public Offerings: Findings and Theories. Boston: Kluwer Academic Publishers.

Ball, R.J., and P. Brown. 1968. An empirical evaluation of accounting income numbers. Journal of Accounting Research 6: 159-178.

Ballester, M., and J. Livnat. 1997. The association between security prices and financial information in the Spanish stock market. Journal of International Financial Man. agement and Accounting 8 (2): 114-136.

Baron, D. 1982. A model of the demand for investment banking advising and distribution scrvices for new issues. Journal of Finance 37 (3): 955-976.

Barry, C. B., and S. J. Brown. 1984. Differential information and the small firm effect. Journal of Financial Economics 13: 283-294.

Bauman, M. P. 1996. A review of fundamental analysis research in accounting. Journal of Accounting Literature 15: 1-33. 
Tatang Aṇ. Gunanti -Can Accounting Information Act as a Proxy for Ex Ante...?

Beatty, R. P. 1989. Auditor reputation and the pricing of initial public offerings. The Accounting Review 64 (3): 693-709.

and E. J. Zajac. 1995. Managerial incentives, monitoring, and risk bearing in initial public offering firms. Journal of Applied Corporate Finance 8 (2): 87-96.

Beaver, W.B. 1986. Financial Reporting: An Accounting Revolution. New Jersey: Prentice-Hall Inc.

P. Kettler, and M. Scholes. 1970. The association between market-determined and accounting determined risk measures. Accounting Review 45 (3): 654-682.

Belkaoui, A. 1978. Accounting determinants of systematic risk in Canadian common stocks: A multivariate approach. Accounting and Business Research 6 (Winter): 310.

Benninga, S.Z., and O.H. Sarig. 1997. Corporate Finance: A Valuation Approach. McGraw-Hill Companies, Inc. North America.

Ben-Zion, U., and S. S. Shalit. 1975. Size, leverage, and dividend record as determinants of equity risk. Journal of Finance 30 (4): 1015-1026.

Bernard, V. L. 1995. The Feltham-Ohlson framework: Implications for empiricists. Contemporary Accounting Research 11 (2): 733-748.

Berstein, L. A., and J. J. Wild. 1998. Financial Statement Analysis: Theory, Application, and Interpretation (6 $6^{\text {th }}$ ed.). Singapore: McGraw Hill.

Black, E. L., B. Chavis, and R. Elmendorf. 1997. The informativeness of financial statement data for emerging-growth firms. Journal of Financial Statement Analysis 3 (2): $29-42$.

Bloch. E. 1986. Inside Investment Banking. Homewood, Illinois: Dow Jones-Irwin.

Bowman, R. G. 1979. The theoretical relationship between systematic risk and financial (accounting) variables. Journal of Finance 34 (3): 617-630.

Brealy, R. A., and S. C. Myers. 1996. Principles of Corporate Finance (5 $5^{\text {th }}$ ed.). McGrawHill.

Brennan, M. J. 1995. A perspective on accounting and stock prices. Journal of Applied Corporate Finance. 8 (2): 43-52.

Brigham, E. F., and L. C. Gapenski. 1991. Financial Management: Theory and Practice (6 $6^{\text {th }}$ ed.). Chicago: The Dryden Press.

Buck, G.C. 1990. Pricing initial public offerings. In Capital Raising and Financial Structure. Edited by Khun. R., Richard D Irwin.

Buckland, R., and E. W. Davis. 1990. The pricing of new issues on the unlisted securities market: The influence of firm size in the context of information content of new issue prospectuses. British Accounting Review 22: 207-222. 
Capstaff, J. 1992. The uselulness of UK accounting and market data for predicting the perceived risk class of securitics. Accounting and Business Research 22 (87) (Summer): 219-228.

Chan. L.K.C.. Y. Hamao, and J. Lakonishok. 1991. Fundamentals and stock returns in Japan. Journal of Finance 46 (5): 1736-1764.

Christic, A. A. 1982. The stochastic behavior of common stock variances: Valuc, leverage, and interest rate effects. Journal of Financial Ecomomics 10 (3): 407-432.

Chung, H. Y., and J. B. Kim. 1994. Financial statement analysis and the profitability of risk-based investment strategy: Evidence from the Korea stock exchange. Advance in International Accounting 6: 117-132.

Clarkson, P.M. 1994. The underpricing of initial public offerings, ex ante uncertainty, and proxy sclection, Accounting and Finance 67-78.

M., A. Dontoh, G. Richardson, and S. F. Sefcik. 1991. Relained ownership and the valuation of initial public offerings: Canadian evidence. Contemporary Accoumting Research 7 (1): 115-131.

DeAngelo, L. E. 1990. Equity valuation and corporate control. Accounting Review 65 (1): 93-112.

Dhingra, H. L. 1982. The impact of accounting variables on slock market measures of risks. Accounting and Business Research 10 (Summer): 193-205.

Downes, D. H.. and R. Heinkel. 1982. Signaling and the valuation of unseasoned new issues. Journal of Finance 37 (1): 1-10.

Eskew, R. K. 1979. The forecasting ability of accounting risk measures: Some additional cvidence. Accounting Review 54 (1): 107-118.

Farrelly. G. E., K.R. Ferris, and W. R. Reichenstein. 1985. Perceived risk, market risk, and accounting determined risk measures. Accounting Review 6) (2): 278-288.

Fcltham, G., and J. A. Ohlson. 1995. Valuation and clean surplus accounting for operating and financial activities. Contemporany Accounting Rescarch 11 (2): 689-731.

Fewings, D. R. 1975. Impact of corporate growth on risk of common stocks. Journal of Finance 30: 525-531.

Financial Accounting Standards Board (1978). Statement of Finamcial Accoumting Concept No. I. USA.

Foster, G. R. 1986. Financial Statement Analysis (2 ${ }^{\text {nd }}$ ed.). New-Jersey: Prentice Hall.

Fricdlan, J. M. 1994. Accounting choices of issuers of initial public offerings. Contemporary Accounting Research 11 (1): 1-31.

Gahlon, J. M. 1981. Operating leverage as a determinant of systematic risk. Jourmal of Business Research 9: 297-308. 
Tetang dri Gumami -Can Accounting Information Act as a Proxy for Ex Ante...?

, and J. A. Gentry. 1982. On the relationship between systematic risk and the degrees of operating and financial leverage. Financial Management 21 (Summer): 15-23.

Gartinkel, J.A. 1993. IPO underpricing, insider selling and subsequent equity offerings: Is underpricing a signal of quality? Financial Management 22 (Spring): 74-83.

Grinblatt. M. and C.Y. Hwang. 1989. Signaling and the pricing of new issues. Journal of Finance 44 (2): 393-420.

Gumanti, T. A. 1996. Earnings management and accounting choices in initial public offerings: Evidence from Indonesia. Unpublished Master Thesis. Perth, Western Australia, Australia: Edith Cowan University.

2000. Accounting Information and the Underpricing of Indonesian Initial Public Offerings, Unpublished Doctorate Dissertation. Edith Cowan University. Perth. Western Australia, Australia.

Hall, C., Y. Hamao, and T. S. Harris. 1994. A comparison of relations between security market prices, returns and accounting measures in Japan and the United States. Journal of International Financial Management and Accounting 5 (1): 47-73.

Hall. W.D., and A. J. Renner. 1988. Lessons that auditors ignore at their own risk. Jourmal of Accountancy (July): 50-58.

Hamada. R.S. 1969. Portfoliơanalysis, market equilibrium and corporate finance. Jourmal of Finance 24: 13-31.

Healy, P. M., and G. K. Palepu. 1993. The effect of firms' financial disclosure strategies on stock prices. Accoumting Horizon 7 (1): 1-11.

Hedge, S. P., and R. E. Miller. 1996. The informational role of debt and the pricing of initial public offerings. In Empirical lssues in Raising Equity Capital: 151-174. Edited by M. Levis. Elsevier. Amsterdam.

Holthausen, R. W., and D. F. Larker. 1992. The prediction of stock return using financial statement information. Journal of Accounting and Economics 373-411.

How, J. C., and J. G. Low. 1993. Fractional ownership and underpricing: Signal of IPO firm value? Pacific-Basin Financial Journal 1: 47-65.

How, J.C., H.Y. Izan, and G.S. Monroe. 1995, Differential information and the underpricing of initial public offerings: Australian evidence. Accounting and Finance 87-105.

How, J. C. 1996. Voluntary forecast disclosure and the underpricing of IPOs. Accounting Research Joumal 9 (1): 17-28.

Ibbotson, R., J. Sindelar, and J. R. Ritter. 1988. Initial public offerings. Journal of Applied Corporate Finance I (Summer): 37-45.

Ibbotson, R., J. Sindelar, and J. R. Ritter. 1994. The market problems with the pricing of initial public offerings. Journal of Applied Corporate Finance 7 (Summer): 66-74. 
James, C., and P. Wier. 1990. Borrowing relationships, intermediations, and the cost of issuing public securities. Journal of Financial Economics 28: 149-171.

Kaplan, R. S. 1978. The information content of financial accounting numbers: A survey of empirical evidence. In The Impact of Accounting Research on Practice and Disclosure. Edited by A.R. Abdel-khalik. Durham. Duke University Press.

Keasey, K., and H. Short. 1992. The underpricing of initial public offerings: Soine UK evidence. International Journal of Management Science 20 (4): 457-466.

Keasey, K., and P. McGuinness. 1992. An empirical investigation of the role of signaling in the valuation of unseasoned equity issues. Accounting and Business Research 22 (86): $133-142$.

Kim, J., I. Krinsky, and J. Lee. 1994. Motives for going public and underpricing: New findings from Korea. Journal of Business, Finance and Accounting 20 (2): 195-211.

Kim, J., I. Krinsky, and J. Lee. 1995a. The valuation of initial public offerings and accounting disclosures in prospectuses: New evidence from Korea. The International Journal of Accounting 29: 46-61.

Kim, J., I. Krinsky, and J. Lee. 1995b. The role of financial variables in the pricing of Korean initial public offerings. Pacific-Basin Finance Journal 3: 449-464.

Kim, M., and J. R. Ritter. 1999. Valuing IPOs. Journal of Financial Economics 53: 409 437.

Klein, A. 1996. Can investors use the prospectus to price initial public offerings?. Journal of Financial Statement Analysis 2 (Fall): 23-39.

Krinsky, I. and W. Rotenberg. 1989a. The valuation of initial public offerings. Contemporary Accounting Research 5 (2), 501-515.

Krinsky, I. and W. Rotenberg. 1989b. Signaling and the valuation of unseasoned new issues revisited. Journal of Financial and Quantitative Analysis 24 (2), 257-266.

Leland, H. E., and D. H. Pyle. 1977. Information asymmetric, financial structure, and financial intermediations. Journal of Finance 32 (2): 371-387.

Lev, B. 1974. On the association between operating leverage and risk. Journal of Financial and Quantitative Analysis 9 (3): 627-641.

1989. On the usefulness of earnings and earnings research: Lessons and directions from two decades of empirical research. Journal of Accounting Research: 153-192.

Loughran, T., J. R. Ritter, and K. Rydqvist. 1994. Initial public offerings: International insights. Pacific-Basin Finance Journal 2: 165-199.

Machfoedz, M. 1994. Financial ratio analysis and the prediction of earnings change in Indoncsia. Kelola Gadjah Mada University Business Review 7 (3): 114-137.

Magnan, M., and D. Cormier. 1997. The impact of forward-looking financial data in IPOs on the quality of financial reporting. The Journal of Financial Statement Analysis 3 (2): 6-17. 
Tatang dri Gumami -Can Accounting Information Act as a Proxy for Ex Ante...?

Mandelker, G. N., and S. G. Rhee. 1984. The impact of degrees of operating and financial leverage on systematic risk of common stock. Journal of Financial and Quantitative Analysis 19 (1): 45-57.

McGuinness, P. 1993. The market valuation of initial public offerings in Hong Kong. Applied Financial Ecomomics 3: 267-281.

Mear. R., and M. Firth. 1988. Risk perceptions of financial analysts and the use of market and accounting data. Accounting and Business Research 18 (72, Autumn): 335-340.

Michaely, R., and W. H. Shaw. 1998. Underwriter choice, institutional holdings, and future IPO performance. In Advances in Quantitative Analysis of Finance and Accounting. Vol. 6. pp. 137-149. Edited by C. Lee.

Myers, S. C. 1977. The determinants of corporate borrowing. Journal of Financial Economics. 5 (November): 147-176.

Myers, S. C., and N. Majluf. 1984. Corporate financing and investment decisions when firms have information and investors do not have. Journal of Fincuncial Economics 13: 187-221.

Noland. T.R., and R. M Pavlik. 1998. The underpricing of initial public offerings: Review. critique. and integration. In Advances in Quantitative Analysis of Finance and Accounting. Vol. 6. pp. 73-102. Edited by C. Lee.

O'Brien, T. J., and P. A. Vanderhciden. 1987. Empirical measurement of operating leverage for growing firms. Financial Management 16 (Summer): 45-53.

Ohlson, J. A. 1995. Earnings, book values, and dividends in equity valuation. Contemporany Accounting Research II (2): 661-687.

Ou. J. A.. and S. H. Penman. 1989. Financial statement analysis and the prediction of stock relurns. Jounal of Accounting and Economics. 295-329.

Palepu. K. G., V. L. Bernard, and P. M. Healy. 1996. Business Analysis and Valuation: Using Financial Statements. Cincinnati. South-Western Publishing Co.

Perez, R.C. 1984. Inside Investment Banking. New York, Prager.

Pettway, R.H., and T. Keneko. 1996. The effects of removing price limits and introducing auctions upon short-term IPO returns: The case of Japanese IPOs, Pacific-Basin Finance Journal 4: 241-258.

Ritter, J. R. 1984. Signaling and the valuation of unseasoned new issues: A comment. Journal of Finance 39 (4): 1231-1237.

Rizka, Y. 1995. Analysis Faktor-faktor yang mempengaruhi underpricing pada penawaran perdana emisi yang listing di Bursa Efek Jakarta periode 1989-1994 (The analysis of the determinants of underpricing in the new issue stock that listing at the Jakarta Stock Exchange for the period 1989-1994). Master Thesis. Yogyakarta, Indonesia: Gadjah Mada University. 
Rock, K. 1986. Why are new issues underpriced. Journal of Financial Economics 15: 187212.

Rosenberg, G., and W. McKibben. 1973. The prediction of systematic and specific risk in common stocks. Journal of Financial and Quantitative Analysis (March): 317 334.

Rubenstein, M. E. 1973. A mean variance synthesis of corporate financial theory. Journal of Finance 18 (1): 167-181.

Ryan, S. G. 1997. A survey of research relating accounting numbers to systematic equity risk. with implication for risk disclosure policy and future research. Accounting Horizons 11 (2): 82-95.

Sautma, R.B. 1998. Kondisi anomali pada emisi saham perdana (IPO) di pasar modal Indonesia serta faktor-faktor yang mempengaruhinya (Anomaly and determinants of Initial Public Offerings in Indonesian capital market). Unpublished Master Thesis. Jakarta, Indonesia: University of Indonesia.

Selva. M. 1995. The association between accounting determined risk measures and analysts' risk perceptions in a medium-sized stock market. Journal of International Financial Management and Accounting. 6 (3). 207-229.

Setiono, B.. and N. Strong. 1998. Predicting stock returns using linancial statement information. Journal of Business. Finance and Accounting 25 (5/6): 631-657.

Slovin, M. B., and J. E. Young. 1990. Bank lending and initial public offerings. Journal of Banking and Finance 14: 729-740.

Stcrling. H.D. 1987, March. The strategy behind IPO pricing. Cash Flows. 32-36.

Sutton, D. P., and W. M. Benedetto. 1988. Initial Public Offerings: A Strategic Planner for Raising Equity Capital. Chicago. Probus Publishing Company.

Tandelilin, E. 1997a. A comparison of some Philippine and Indonesian common stocks in selected financial accounting ratios and securities systematic risk. Kelola Gadjah Mada University Business Review VI (14): 53-81.

- 1997b. Determinants of systematic risk: The experience of some Indonesian common stock. Kelola Gadjah Mada University Business Review VI (16): 101-115.

Teoh, S.H., I. Welch., and Wong. T.J. 1998. Earnings management and the long-term market performance of initial public offerings. Journal of Finance 53 (4): 19351974.

Titman, S., and B. Trueman. 1986. Information quality and the valuation of new issues. Joumal of Accounting and Economics: 159-172.

Turnbull, S. M. 1977. Market value and systematic risk. Journal of Finance 32 (4): 1125 1143.

Watts, R.L., and J. L. Zimmerman. 1986. Positive Accounting Theory (2 ${ }^{\text {mt }}$ ed.) New Jersey: Prentice-Hall Inc. 
Tutang An. Gumanti - Can Accounting Information Act as a Proxy for Ex Ante...?

Welch, 1. 1989. Seasoned offerings, imitation costs, and underpricing of initial public offerings. Journal of Finance 44 (2): 421-429.

Wethyavivorn. K., and Y. Koo-smith. 1991. Initial public offers in Thailand 1988-1989: Price and returns patterns. In Pacific-Basin Capital Markets Research II: 379-394. Edited by S.G. Rhee and R.P. Chang (Eds.). Amsterdam, North Holland.

White. G.I., A. C. Sondhi, and D. Fried. 1998. The Analysis and Use of Financial Statements (2nd ed.). New York: John Wiley and Sons. Inc.

Whittington. G. 1980. Some basic properties of accounting ratios. Journal of Business Finance and Accounting 7 (2) (Summer): 219-232. 